\title{
The Use of Technology in English Language Learning: A Literature Review
}

\section{Mohammad Reza Ahmadi ${ }^{*}$}

* Correspondence:

mr.ahmadi2720@gmail.com

${ }^{1}$ Guilan University, Guilan, Iran

Received: 30 October 2017

Accepted: 10 January 2018

Published online: 20 June 2018

\section{Abstract}

The use of technology has become an important part of the learning process in and out of the class. Every language class usually uses some form of technology. Technology has been used to both help and improve language learning. Technology enables teachers to adapt classroom activities, thus enhancing the language learning process. Technology continues to grow in importance as a tool to help teachers facilitate language learning for their learners. This study focuses on the role of using new technologies in learning English as a second/foreign language. It discussed different attitudes which support English language learners to increase their learning skills through using technologies. In this paper, the researcher defined the term technology and technology integration, explained the use of technology in language classroom, reviewed previous studies on using technologies in improving language learning skills, and stated certain recommendations for the better use of these technologies, which assist learners in improving their learning skills. The literature review indicated that the effective use of new technologies improves learners' language learning skills.

Keywords: technology, language learning, use 


\section{Introduction}

Language is one of the significant elements that affects international communication activities. Students utilize different parts of English language skills such as listening, speaking, reading, and writing for their proficiency and communication (Grabe \& Stoller, 2002). In addition, Ahmadi (2017) stated that one of the important elements for learning is the method that instructors use in their classes to facilitate language learning process. According to Becker (2000), computers are regarded as an important instructional instrument in language classes in which teachers have convenient access, are sufficiently prepared, and have some freedom in the curriculum. Computer technology is regarded by a lot of teachers to be a significant part of providing a high-quality education.

According to Bull and Ma (2001), technology provides offers unlimited resources to language learners. Harmer (2007) and Genç lter (2015) emphasized and teachers should encourage learners to find appropriate activities through using computer technology in order to be successful in language learning. Clements and Sarama (2003) declare that the use of suitable technological materials can be useful for learners. According to Harmer (2007), using computer-based language activities improve cooperative learning in learners.

Furthermore, Tomlison (2009) and Genç lter (2015) say that computer-based activities provide learners rapid information and appropriate materials. They continue that internet materials motivate learners to learn more. In addition, Larsen-Freeman and Anderson (2011) supported the view that technology provides teaching resources and brings learning experience to the learners' world. Through using technology, many authentic materials can be provided to learners and they can be motivated in learning language.

Technology has always been an important part of teaching and learning environment. It is an essential part of the teachers' profession through which they can use it to facilitate learners' learning. When we talk about technology in teaching and learning, the word 'integration' is used. With technology being part of our everyday lives, it is time to rethink the idea of integrating technology into the curriculum and aim to embed technology into teaching to support the learning process. That is to say, technology becomes an integral part of the learning experience and a significant issue for teachers, from the beginning of preparing learning experiences through to teaching and learning process (Eady \& Lockyer, 2013).

Solanki and Shyamlee1 (2012) and Pourhosein Gilakjani (2017) supported the view that language teaching method has been changed due to technology. The researchers continued that the application of technology helps learners learn on the basis of their interests. It also satisfies both visual and auditory senses of the learners. According to Lam and Lawrence (2002) and Pourhosein Gilakjani (2017), technology assists learners in adjusting their own learning process and they can have access to a lot of information that their teachers are not able to provide.

According to Pourhosein Gilakjani (2013), the use of technologies has the great potential to change the existing language teaching methods. Pourhosein Gilakjani and Sabouri (2014) emphasized that 
through using technology, learners can control their own learning process and have access to many information over which their teachers cannot control. Technology has an important role in promoting activities for learners and has a significant effect on teachers' teaching methods. If teachers do not use technologies in their teaching they will never be able to keep up with these technologies. Thus, it is very important for teachers to have a full knowledge of these technologies in teaching language skills (Pourhosein Gilakjani, 2017; Solanki \& Shyamlee1, 2012).

Developing learners' knowledge and skills pertinent to computer technology provides equity of opportunity, regardless of learners' background. Although learners have been born into a technologically rich world, they may not be skilful users of technology (Bennett, Maton \& Kervin, 2008). In addition, just providing access to technology is not adequate. Meaningful development of technology-based knowledge is significant for all learners in order to maximize their learning (OECD, 2010). In this review paper, the researcher will review some of the significant issues pertinent to the use of technology in the learning and teaching of English language skills. These issues are as follows: definition of technology, the use of technology in the classroom, previous studies on using technologies in improving English language learning skills, and recommendations for using technologies.

\section{Definition of Technology and Technology Integration}

Technology has been defined by different researchers. According to İ̧MAN (2012), it is the practical use of knowledge particularly in a specific area and is a way of doing a task especially using technical processes, methods, or knowledge. The usage of technology includes not only machines (computer hardware) and instruments, but also involves structured relations with other humans, machines, and the environment (İŞMAN, 2012).

According to Hennessy, Ruthven, and Brindley (2005) and Pourhosein Gilakjani (2017), technology integration is defined in terms of how teachers use technology to perform familiar activities more effectively and how this usage can re-shape these activities. Dockstader (2008) defined technology integration as the use of technology to improve the educational environment. It supports the classroom teaching through creating opportunities for learners to complete assignments on the computer rather than the normal pencil and paper.

\section{Use of Technology in English Language Class}

Technology is an effective tool for learners. Learners must use technology as a significant part of their learning process. Teachers should model the use of technology to support the curriculum so that learners can increase the true use of technology in learning their language skills (Costley, 2014; Murphy, DePasquale, \& McNamara, 2003). Learners' cooperation can be increased through technology. Cooperation is one of the important tools for learning. Learners cooperatively work together to create tasks and learn from each other through reading their peers' work (Keser, Huseyin, \& Ozdamli, 2011). 
Bennett, Culp, Honey, Tally, and Spielvogel (2000) asserted that the use of computer technology lead to the improvement of teachers' teaching and learners' learning in the classes. The use of computer technology helps teachers meet their learners' educational needs. According to Bransford, Brown, and Cocking (2000), the application of computer technology enables teachers and learners to make local and global societies that connect them with the people and expand opportunities for their learning. They continued that the positive effect of computer technology does not come automatically; it depends on how teachers use it in their language classrooms.

According to Susikaran (2013), basic changes have come in classes beside the teaching methods because chalk and talk teaching method is not sufficient to effectively teach English. Raihan and Lock (2012) state that with a well-planned classroom setting, learners learn how to learn efficiently. Technology-enhanced teaching environment is more effective than lecture-based class. Teachers should find methods of applying technology as a useful learning instrument for their learners although they have not learnt technology and are not able to use it like a computer expert.

The application of technology has considerably changed English teaching methods. It provides so many alternatives as making teaching interesting and more productive in terms of advancement (Patel, 2013). In traditional classrooms, teachers stand in front of learners and give lecture, explanation, and instruction through using blackboard or whiteboard. These method must be changed concerning the development of technology. The usage of multimedia texts in classroom assists learners in become familiar with vocabulary and language structures. The application of multimedia also makes use of print texts, film, and internet to enhance learners' linguistic knowledge. The use of print, film, and internet gives learners the chance to collect information and offers them different materials for the analysis and interpretation of both language and contexts (Arifah, 2014).

Dawson, Cavanaugh, and Ritzhaupt (2008) and Pourhosein Gilakjani (2014) maintained that using technology can create a learning atmosphere centered around the learner rather than the teacher that in turn creates positive changes. They emphasized that by using computer technology, language class becomes an active place full of meaningful tasks where the learners are responsible for their learning. Drayton, Falk, Stroud, Hobbs, and Hammerman (2010) argued that using computer technology indicates a true learning experience that enhances learners' responsibilities. Technology encourages learners to learn individually and to acquire responsible behaviors. The independent use of technologies gives learners self-direction.

According to Arifah (2014), the use of internet increases learners' motivation. The use of film in teaching helps learners to realize the topic with enthusiasm and develop their knowledge. Learners can learn meaningfully when technology is used in the process of learning through using computer and internet. When learners learn with technology, it assists them in developing their higher order thinking skills. It can be concluded that the true combination of multimedia and teaching methodology is very important to attract learners' attention towards English language learning. 


\section{Previous Studies on the Benefits of Technology in Improving Language Skills}

Some studies have been done on the advantages of using technology in English language teaching and learning. Hennessy (2005) stated the use of ICT acts as a catalyst in motivating teachers and learners to work in new ways. The researcher understood that as learners become more autonomous, teachers feel that they should urge and support their learners to act and think independently. The application of Computer Assisted Language Learning (CALL) changes learners' learning attitudes and enhances their self-confidence (Lee, 2001).

Information and communication technologies (ICTs) have some benefits for teaching and learning. First, learners play an active role, which can help them retain more information. Next, follow-up discussions involve more information where learners can become more independent. Finally, learners can process new learner-based educational materials and their language learning skills can increase (Costley, 2014; Tutkun, 2011).

The use of technology has changed the methods from teacher-centered to learner-centered ones. Teachers should be facilitators and guide their learners' learning and this change is very useful for learners to increase their learning (Riasati, Allahyar, \& Tan, 2012). Gillespie (2006) said that the use of technology increases learners' cooperation in learning tasks. It assists them in gathering information and interacting with resources such as videos.

Warschauer (2000a) described two different views about how to integrate technology into the class. First, in the cognitive approach, learners get the opportunity to increase their exposure to language meaningfully and make their own knowledge. Second, in the social approach, learners must be given opportunities for authentic social interactions to practice real life skills. This objective can be obtained through the collaboration of learners in real activities.

Eaton (2010) told that computer-based communication is a useful feature for language learning. Computer-assisted discussion features more equal participation than face to-face discussion. Zhao (2013) supported the above view and said that access to authentic materials in the target language is critical for successful language learning.

According to Rodinadze and Zarbazoia (2012), technology helps learners and teachers in studying the course materials owing to its fast access. Advancements in technology have a key role in preparing learners to use what they learn in any subject matter to finding their place in the world labor-force. Technology facilitates learners' learning and serves as a real educational tool that allows learning to occur.

Baytak, Tarman, and Ayas (2011) carried out a on the role of technology in language learning. The results revealed learners' learning was improved by integrating technology into the classroom. Learners stated that the use of technology in school makes learning enjoyable and helps them learn more. Learners also said that technology makes learning interesting, enjoyable, and interactive. The other outcome of this research was that the use of technology increases learners' motivation, social interactions, learning and engagement. 
Mouza (2008) and Sabzian, Pourhossein Gilakjani, and Sodouri (2013) asserted that one of the impacts of using technology in the language classes is the increase in cooperation among teachers and learners. When teachers allow learners to become assistants in the teaching process, this can increase learners' confidence. Learners are granted the chance to reinforce opinions and abilities already learnt. Learners can help teachers in technology integration because learners have had abundant time to master technology while teachers work on directing the instruction.

Drayton, Falk, Hobbs, Hammerman, and Stroud (2010) also emphasized that the use of computerbased classroom shows a real learning experience that increases learners' responsibility. Teachers said that the use of Internet and e-mail urges learner-centered learning. Warschauer (2000) and Parvin and Salam (2015) carried out a study and declared that by using technology, learners get the chance to increase their exposure to language in a meaningful context and make their own knowledge. Learners should have opportunities for social interactions to practice real life skills. This is achieved through learners' cooperation in real activities.

Baytak, Tarman, and Ayas (2011) performed a research towards the effect of technology on learning. The findings obtained from this study revealed that learners increased their learning through incorporating technology into their classes. The researchers emphasized that technology made learners' learning interesting and interactive and increased their motivation, social interactions, and engagement.

Peregoy and Boyle (2012) carried a study on using technology in improving learners' reading and writing skills. The results of this study indicated that technology tools enhanced learners' reading and writing skills because they are user-friendly, and learners can learn at a faster and more effective way. The other finding of this study was that leaners learn more effectively when they use technology tools instead of traditional teaching method because the Internet provided a favorable learning environment for learners' learning, facilitated a new platform for learners who can have a convenient access to learning lessons.

The other study was done by Alsaleem (2014) on using WhatsApp applications in English dialogue journals to improve learners' writing, vocabulary, word choice, and speaking ability. Based on the results of this study, it was concluded that WhatsApp showed improvement in learners' writing skills, speaking skill, vocabulary, and word choice. Godzicki, Godzicki, Krofel, and Michaels (2013) performed a study on examining students' motivation and engagement in the classroom. The findings obtained from this study revealed that students were more likely to engage in classroom when technology is used as an educational tool inside the class. Technology tools show an improvement when it comes down to accessibility and motivation.

Lin and Yang (2011) performed a study to investigate whether Wiki technology would improve learners' writing skills. Learners were invited to join a Wiki page where they would write passages and then read and answer the passages of their fellow classmates. Learners indicated that the immediate feedback they received was a benefit of using this kind of technology. Another finding 
was that learners learned vocabulary, spelling, and sentence structure by reading the work of their classmates.

\section{Recommendations for the Successful Integration of Technology}

In the following section, the researcher presents some recommendations for learners to improve their language skills through using technology:

1. Teachers should implement a technology plan that considers integration strategies along with purchasing decisions (Pourhossein Gilakjani, Leong, \& Hairul, 2013).

2. Professional development should be specifically considered in order to assure learners' learning and to change the attitudes of teachers unfamiliar with the advantages that technology provides (Pourhossein Gilakjani, Leong, \& Hairul, 2013).

3. The technology plan must be closely aligned with the curriculum standards. Teachers should know what educational approach is the most effective one when integrating technologies in the classroom (Pourhossein Gilakjani, Leong, \& Hairul, 2013).

4. The computer technology is an integral part of the learning activity through which skills are transferred to learners.

5. Language teachers should urge their learners to use technology in developing their language skills.

6. Universities should regard technology as a significant part of teaching and learning programs.

7. Technology experts should provide extra assistance for teachers who use it in teaching their English courses.

8. Teachers should be a pattern for their learners in using computer technology (MEB, 2008; Pourhossein Gilakjani, \& Sabouri, 2017).

9. Teachers should create technology-integrated lesson materials. These materials should concentrate on teaching and learning, not just on technology issues.

10. Teachers should find the ways that technology can help them towards learner-centered instruction as opposed to teacher-centered instruction.

11. Teachers should be aware of their roles as guides and facilitators of their learners' learning (Molaei \& Riasati, 2013; Pourhossein Gilakjani, \& Sabouri, 2017).

12. In order to facilitate the integration of technology, enough support and technical assistance should be provided for teachers.

13. Training should be provided for teachers to learn how to use and teach it effectively.

14. Teachers should seek the guidance from their colleagues who can help them teach better through using technology. 
15. Technology is one of the important tools of language learning activity; it helps learners to improve their language learning skills.

16. Teachers should encourage their learners to use technology in increasing their language abilities.

\section{Conclusion}

In this paper, the researcher reviewed some important issues pertinent to the use of technology in language learning. The literature review indicated that technology resources cannot guarantee teachers' teaching and learners' learning. Teachers should be convinced of the usefulness and advantages of technology in improving learners' learning. This means that teachers need support and training for integrating technology into language teaching. The review revealed that when technology is used appropriately, it can bring about a lot of advantages to teachers and learners. It is a resource that can be used by learners because it helps them solve their learning problems and find methods to use what they have learnt in ways that are effective and meaningful. In addition, the review literature indicated that the use of technologies plays a key role in language learning based on their own pace, helps in self-understanding, does not stop interaction with the teacher, and creates high motivation in learners for the effective learning of language skills. Furthermore, the paper represented that learners should use technology to enhance their language skills because it has as a crucial role in developing learners' creativity and provides them with interesting, enjoyable, and exciting alternatives to study the language. To sum up, the findings of this literature review showed that technology provides interaction between teachers and learners, provides comprehensible input and output, helps learners to develop thinking skills, makes learning and teaching becomes more student-centered, promotes learners' autonomy and helps them feel more confident, and increases learners' motivation to effectively learn a foreign language.

\section{References}

Ahmadi, M. R. (2017). The impact of motivation on reading comprehension. International Journal of Research in English Education. http://www.ijreeonline.com

Alsaleem, B. I. A. (2014). The effect of “WhatsApp” electronic dialogue journaling on improving writing vocabulary word choice and voice of EFL undergraduate Saudi Students. Harvard: 21st Century Academic Forum Conference Proceedings. http://www.readwritethink.org/lesson_images/lesson782/Rubric.pdf

Arifah, A. (2014). Study on the use of technology in ELT classroom: Teachers' perspective. M.A. Thesis, Department of English and Humanities, BRAC University, Dhaka, Bangladesh.

Baytak, A., Tarman, B., \& Ayas, C. (2011). Experiencing technology integration in education: children's perceptions. International Electronic Journal of Elementary Education, 3(2), $139-151$. https://www.iejee.com/index.php/IEJEE/article/view/233. Date accessed: 17 June 2018.

Becker, H. J. (2000). Findings from the teaching, learning, and computing survey: Is Larry Cuban right? Education Policy Analysis Archives, 8(51). doi: http://dx.doi.org/10.14507/epaa.v8n51.2000 
Bennett, D., Culp, K. M., Honey, M., Tally, B., \& Spielvogel, B. (2000). It all depends: Strategies for designing technologies for educational change. Paper presented at the International Conference on Learning Technology, Philadelphia, PA.

Bennett, S., Maton, K., \& Kervin, L. (2008). The 'digital natives' debate: A critical review of the evidence. British Journal of Educational Technology, 39(5), 775-86. https://doi.org/10.1111/j.1467-8535.2007.00793.x

Bransford, J., Brown, A., \& Cocking, R. (2000). How people learn: Brain, mind, experience, and school. Washington, DC: National Academic Press.

Bull, S., \& Ma, Y. (2001) Raising learner awareness of language learning strategies in situations of limited recourses. Interactive Learning Environments, 9(2), 171-200. doi: 10.1076/ilee.9.2.171.7439

Clements, D. H., \& Sarama, J. (2003). Strip mining for gold; research and policy in educational technology-a response to fool's gold. Educational Technology Review, 11(1), 7-69. https://eric.ed.gov/?id=EJ673505

Costley, K. C. (2014). The positive effects of technology on teaching and student learning. Arkansas Tech University.

Dawson, K., Cavanaugh, C., \& Ritzhaupt, A. (2008). Florida's EETT Leveraging Laptops Initiative and its impact on teaching practices. Journal of Research on Technology in Education, 41(2), 143-159. https://doi.org/10.1080/15391523.2008.10782526

Dockstader, J. (2008). Teachers of the 21st century know the what, why, and how of technology integration. Retrieved from http://the-tech.mit.edu/Chemicool/

Drayton, B., Falk, J. K., Stroud, R., Hobbs, K., \& Hammerman, J. (2010). After installation: Ubiquitous computing and high school science in three experienced, high-technology schools. Journal of Technology, Learning, and Assessment, 9(3), 1-57. https://eric.ed.gov/?id=EJ873677

Eady, M. J., \& Lockyer, L. (2013). Tools for learning: technology and teaching strategies: Learning to teach in the primary school. Queensland University of Technology, Australia. pp. 71-89. https://scholars.uow.edu.au/display/publication76376

Eaton, S. E. (2010). Global trends in language learning in the twenty-first century. Calgary, Canada: Onate Press. https://files.eric.ed.gov/fulltext/ED510276.pdf

Gençlter, B. (2015). How does technology affect language learning process at an early age? Procedia - Social and Behavioral Sciences, 199(2015), 311 - 316. doi: 10.1016/j.sbspro.2015.07.552

Gillespie, H. (2006). Unlocking learning and teaching with ICT: Identifying and overcoming barriers. London: David Fulton. https://trove.nla.gov.au/work/20064464

Godzicki, L., Godzicki, N., Krofel, M., \& Michaels, R. (2013). Increasing motivation and engagement in elementary and middle school students through technology-supported learning environments. Retrieved from http://www.eric.ed.gov.ezproxy.cu-portland.edu/contentdelivery/servlet/ERICServlet?accno=ED541343

Grabe, W., \& Stoller, F. L. (2002). Teaching and researching reading. New York: Pearson Education. doi: $\underline{10.4324 / 9781315833743}$

Harmer, J. (2007). The practice of English language teaching. England: Pearson. www.worldcat.org/title/practice-ofenglish-language-teaching/oclc/149005881

Hennessy, S. (2005). Emerging teacher strategies for supporting. Cambridge, UK: University of Cambridge.

Hennessy, S., Ruthven, K., \& Brindley, S. (2005). Teacher perspectives on integrating ICT into subject teaching: Commitment, constraints, caution, and change. Journal of Curriculum Studies, 37(2), 155-192. 
http://dx.doi.org/10.1080/0022027032000276961

İ̧MAN, A. (2012). Technology and technique: An educational perspective. TOJET: The Turkish Online Journal of Educational Technology, 11(2), 207-213. tojet.net/articles/v11i2/11222.pdf

Keser, H., Uzunboylu, H., \& Ozdamli, F. (2012). The trends in technology supported collaborative learning studies in 21st century. World Journal on Educational Technology, 3(2), 103-119.

Lam, Y., \& Lawrence, G. (2002). Teacher-student role redefinition during a computer-based second language project: Are computers catalysts for empowering change? Computer Assisted Language Learning, 15(3), $295-315$. https://doi.org/10.1076/call.15.3.295.8185

Larsen- Freeman, D., \& Anderson, M. (2011). Techniques and principles in language teaching. Oxford: OUP.

Lin, W., \& Yang, S. (2011). Exploring students' perceptions of integrating Wiki technology and peer feedback into English writing courses. English Teaching: Practice and Critique, 10(2), 88-103. https://eric.ed.gov/?id=EJ944900

Mouza, C. (2008). Learning with laptops: Implementation and outcomes in an urban, underprivileged school. Journal of Research on Technology in Education, 40(4), 447-472. https://eric.ed.gov/?id=EJ826086

Murphy, K., DePasquale, R., \& McNamara, E. (2003). Meaningful Connections: Using Technology in Primary Classrooms. Young Children, 58(6), 12-18. Retrieved June 17, 2018 from https://www.learntechlib.org/p/101494/.

Organization for Economic Co-operation and Development (OECD). (2010). Are the new millennium learners making the grade? Technology use and educational performance in PISA: Centre for Educational Research and Innovation, OECD.

Parvin, R. H., \& Salam, S. F. (2015). The effectiveness of using technology in English language classrooms in government primary schools in Bangladesh. FIRE: Forum for International Research in Education, 2(1), 4759. http://preserve.lehigh.edu/fire/vol2/iss1/5

Patel, C. (2013). Use of multimedia technology in teaching and learning communication skill: An analysis. International Journal of Advancements in Research \& Technology, 2(7), 116-123.

Peregoy, S., \& Boyle, O. (2012). Reading, writing and learning in ESL: A resource book for teachers. New York: Allyn \& Bacon.

Pourhossein Gilakjani, A. (2013). Factors contributing to teachers' use of computer technology in the classroom. Universal Journal of Educational Research, 1(3), 262-267. doi: 10.13189/ujer.2013.010317

Pourhossein Gilakjani, A. (2014). A detailed analysis over some important issues towards using computer technology into the EFL classrooms. Universal Journal of Educational Research, 2(2), 146-153. doi: 10.13189/ujer.2014.020206

Pourhossein Gilakjani, A. (2017). A review of the literature on the integration of technology into the learning and teaching of English language skills. International Journal of English Linguistics, 7(5), 95-106. doi: https://doi.org/10.5539/ijel.v7n5p95

Pourhossein Gilakjani, A., Leong, L. M., \& Hairul, N. I. (2013). Teachers' use of technology and constructivism. I. J. Modern Education and Computer Science, 4, 49-63. doi: 10.5815/ijmecs.2013.04.07 
Pourhossein Gilakjani, A., \& Sabouri, N. B. (2014). Role of Iranian EFL teachers about using Pronunciation Power software in the instruction of English pronunciation. English Language Teaching, 7(1), 139-148. doi: http://dx.doi.org/10.5539/elt.v7n1p139

Pourhossein Gilakjani, A., \& Sabouri, N. B. (2017). Advantages of using computer in teaching English pronunciation. International Journal of Research in English Education (IJREE), 2(3), 78-85. doi: $\underline{10.18869 / \text { acadpub.ijree.2.3.78 }}$

Raihan, M. A., \& Lock, H. S. (2010). Technology integration for meaningful learning-the constructivist view. Bangladesh Educational Journal, 11(1), 17-37.

Riasati, M. J., Allahyar, N., \& Tan, K. E. (2012). Technology in language education: Benefits and barriers. Journal of Education and Practice, 3(5), 25-30. www.iiste.org > Home > Vol 3, No 5 (2012) > Riasati

Rodinadze, S., \& Zarbazoia, K. (2012). The advantages of information technology in teaching English language.

Frontiers of Language and Teaching, 3(5), 271-275.

Sabzian, F., Pourhossein Gilakjani, A., \& Sodouri, S. (2013). Use of technology in classroom for professional development. Journal of Language Teaching and Research, 4(4), 684-692. doi:10.4304/jltr.4.4.684-692

Solanki, D., \& Shyamlee1, M. P. (2012). Use of technology in English language teaching and learning: An analysis. 2012International Conference on Language, Medias and Culture IPEDR vol. 33(2012)@(2012)IACSIT Press, Singapore. 150-156.

Susikaran, R. S. A. (2013). The use of multimedia in English language teaching. Journal of Technology for ELT, 3(2). https://sites.google.com/site/journaloftechnologyforelt/archive/3-2-april-2013/1-the-use-of-multimedia-inenglish-language-teaching

Tomlinson, B. (2009). Materials development in language teaching. Cambridge: Cambridge University Press.

Warschauer, M. (2000a). The death of cyberspace and the rebirth of CALL. English Teachers' Journal, 53, 61-67. [Online.] Available: http://www.gse.uci.edu/markw/cyberspace.html

Zhao, Y. (2013). Recent developments in technology and language learning: Literature review and meta-analysis. CALICO Journal, 21(1), 7-27. https://eric.ed.gov/?id=EJ674877 